\title{
Phytopathology"
}

\section{Fusarium Head Blight in Durum Wheat: Recent Status, Breeding Directions, and Future Research Prospects}

\author{
Jemanesh K. Haile, ${ }^{1, \dagger}$ Amidou N’Diaye, ${ }^{1}$ Sean Walkowiak, ${ }^{1}$ Kirby T. Nilsen, ${ }^{1}$ John M. Clarke, ${ }^{1}$ Hadley R. Kutcher, ${ }^{1}$ \\ Barbara Steiner, ${ }^{2}$ Hermann Buerstmayr, ${ }^{2}$ and Curtis J. Pozniak ${ }^{1}$
}

\begin{abstract}
${ }^{1}$ Department of Plant Sciences, Crop Development Centre, University of Saskatchewan, 51 Campus Drive, S7N 5A8, SK, Saskatoon, Canada ${ }^{2}$ Department of Agrobiotechnology, Institute of Biotechnology in Plant Production, BOKU-University of Natural Resources and Life Sciences Vienna, Konrad Lorenz Str. 20, 3430 Tulln, Austria

Accepted for publication 29 July 2019.
\end{abstract}

\begin{abstract}
Fusarium head blight (FHB) is a major fungal disease affecting wheat production worldwide. Since the early 1990s, FHB, caused primarily by Fusarium graminearum, has become one of the most significant diseases faced by wheat producers in Canada and the United States. The increasing FHB problem is likely due to the increased adoption of conservation tillage practices, expansion of maize production, use of susceptible wheat varieties in rotation, and climate variability. Durum wheat (Triticum turgidum sp. durum) is notorious for its extreme susceptibility to FHB and breeding for resistance is complicated because sources of FHB resistance are rare in the primary gene pool of tetraploid wheat. Losses due to this disease include yield, test weight, seed quality, food and feed quality, and when severe, market access. More importantly, it is the contamination with mycotoxins, such as deoxynivalenol, in Fusarium-infected durum kernels that causes the most serious economic as well as food and feed safety concerns. Several studies and thorough reviews have been published on germplasm development and breeding for FHB resistance and the genetics and genomics of FHB resistance in bread or common wheat (T. aestivum); however, similar reviews have not been conducted in durum wheat. Thus, the aim of this review is to summarize and discuss the recent research efforts to mitigate FHB in durum wheat, including quantitative trait locus mapping, genome-wide association studies, genomic prediction, mutagenesis and characterization of genes and pathways involved in FHB resistance. It also highlights future directions, FHB-resistant germplasm, and the potential role of morphological traits to enhance FHB resistance in durum wheat.
\end{abstract}

Keywords: breeding, biological control, disease control and pest management, durum wheat, Fusarium graminearum, Fusarium head blight, genetics and resistance, resistance

Durum wheat (Triticum turgidum L. sp. durum) is a widely grown crop that is used in the preparation of a range of food products including bread, couscous, and most importantly pasta. Worldwide, more than 21 countries produce durum wheat on approximately 18 million hectares, with an annual production of about 35 million tons (Cakmak et al. 2010). Canada is among the largest producers and exporters of durum wheat, with a production volume of about 7.8 million tons in 2017 (Statistics Canada 2018). About 7.5 million tons of durum wheat were produced in Europe in 2015/16, of which almost half (3.9 million tons) was produced in Italy, followed by Turkey and France with average production of 2.7 and 1.7 million tons, respectively (Tedone et al. 2017).

${ }^{\dagger}$ Corresponding author: J. K. Haile; jemanesh.haile@usask.ca

The author(s) declare no conflict of interest.

(C) 2019 The American Phytopathological Society
Over 200 plant diseases have been reported on wheat, 50 of which cause economic losses, varying according to region and climate (Wiese et al. 2000). Among all pathogens, fungi are the main and most common agents of disease (Bockus et al. 2010; Zhou 2011). Fusarium head blight (FHB) is a major fungal disease; the predominant species causing this disease include $F$. graminearum (teleomorph Gibberella zeae), F. culmorum and F. avenaceum (teleomorph Gibberella avenacea) (Buerstmayr et al. 2009). $F$. graminearum is often the prevalent species in many of the affected regions (Osborne and Stein 2007)), most notably, in North America (Gale 2003; Shaner 2003) and in Italy (Beccari et al. 2017). F. graminearum persists as a saproprobe on crop residues. Its inoculum is primarily composed of ascospores and macroconidia (Osborne and Stein 2007). Sexual spores, ascospores, produced in perithecia are forcibly discharged into the air and serve as the primary inoculum, typically near flowering (anthesis) (Trail 2009). Asexual spores, macroconidia, are produced by $F$. graminearum mycelia present on the infected plants and can be water splashed onto adjacent plants and their developing spikes. 
During the infection process, Fusarium species are capable of producing a number of trichothecene mycotoxins, including deoxynivalenol (DON) and nivalenol (NIV), as well as other secondary metabolites, such as zearalenone (ZEA) and moniliformin (MON) (Chilaka et al. 2017), all of which have a range of toxicity effects on humans and animals (Häggblom and Nordkvist 2015) and are thus a significant hazard in the food chain (Magan and Aldred 2007). The DON producing strains can produce different acetylated variants of the trichothecene mycotoxin and can be further subgrouped into 3-acetyl-DON (3-ADON) and 15acetyl-DON (15-ADON) chemotypes depending on whether the C-15 or C-3 acetyl group is present. These chemotypes have diverged into distinct populations, with the population corresponding to the 3-ADON chemotype being more aggressive and becoming more prevalent in Canada and the United States (Kelly et al. 2015; Walkowiak et al. 2015).

In general, wheat is susceptible to Fusarium infection from anthesis to the soft dough stage of kernel development (McMullen et al. 2012). Morphological and developmental characteristics such as plant height (Klahr et al. 2007; Yan et al. 2011), heading date (Klahr et al. 2007; Wilde et al. 2007), anther extrusion (Buerstmayr and Buerstmayr 2015; Skinnes et al. 2010), head compactness (Lu et al. 2012; Schmolke et al. 2005), and content and composition of cell wall polymers (Lionetti et al. 2015) may affect resistance. In bread wheat, genetic variation for FHB resistance is large and a range of resistance sources from "exotic" and "native" wheat germplasm are known (Steiner et al. 2017). On the contrary, durum is notorious for its extreme susceptibility to FHB (Miedaner et al. 2017) and breeding for FHB resistance is difficult due to the lack of resistance sources (Miedaner 1997) and difficulties in efficiently combining the numerous small-effect resistance quantitative trait locus (QTL) (Steiner et al. 2018).

Several studies and thorough reviews have been published about germplasm development and breeding for FHB resistance and genetics and genomics of the resistance in bread wheat. In particular, the genetics of host resistance (Buerstmayr et al. 2014), QTL mapping, and FHB breeding strategies based on DNA markers (Anderson 2007; Bai et al. 2018) and sources for FHB resistance improvement and available options for selection (Prat et al. 2014; Steiner et al. 2017) have been published. Dweba et al. (2017) and Gilbert and Haber (2013) highlighted FHB pathogenesis, the pathogen $F$. graminearum and its infection mechanisms and chemotypic distribution and Bai and Shaner (2004) documented the management of FHB in bread wheat mainly from a North American perspective. In contrast, there is limited information about FHB in durum wheat. Thus, the objectives of this review are to (i) summarize the effects of FHB on end-use quality of durum wheat; (ii) review the research efforts for FHB resistance in durum wheat; and (iii) update the current achievements in developing FHB resistant germplasm and suggest future strategies.

\section{WHY FHB IS A CONCERN}

FHB is a global problem that has a great economic impact on the cereal industry due to reduced seed quality and yield. Since the early 1990s, FHB has become one of the most significant cereal diseases faced by producers in Canada and in the midwestern United States (Gilbert and Tekauz 2000; Turkington et al. 2014). This is likely due to multiple factors, including the adoption of conservation tillage practices, expansion of maize production, dynamics in pathogen populations, and climate variability (Scala et al. 2016). To exemplify the magnitude of the problem, about $65 \%$ of the spring common wheat and $36 \%$ of the durum was downgraded due to FHB in 2016 in Saskatchewan, Canada, costing farmers an estimated $\$ 1$ billion in lost revenue (Canadian Grain Commission 2018); as a result, FHB is getting more attention as a research problem in
Canada. FHB is also an increasing concern in Europe; for example, the increasing demand for durum-derived products has led to an expansion of the durum cultivation area, from the typically hot and dry Mediterranean growing regions to more wet and rainy regions in Central and Western Europe, which has intensified the risk of FHB incidence on durum wheat (Giancaspro et al. 2016).

Dynamics in the pathogen population may also play a role in the incidence of disease. Several studies in Canada and the United States indicate that while 15 -ADON used to be the dominant chemotype, 3-ADON has become increasingly prevalent over for the last 20 years. Climatic conditions experienced during the preceding cropping season may influence FHB species complex composition on wheat because of the impact of high temperatures on the survival and production of Fusarium spp. inoculum on crop residues (Covarelli et al. 2015). In addition, winter conditions also seem to have an influence on the FHB species complex composition, due to the impact of low temperatures and of the length of periods below $0^{\circ} \mathrm{C}$ on overwintering Fusarium spp. (Beccari et al. 2017b). Kelly et al. (2015) identified $F$. graminearum strains that produce the recently discovered A-trichothecene mycotoxin (NX-2) for the first time in Canada, representing a significant expansion of the known range of NX-2 producing strains in North America.

\section{EFFECT OF FHB ON YIELD AND END-USE QUALITY OF DURUM WHEAT}

Yield losses and reduced seed quality are direct consequences of FHB in both bread and durum wheat (McMullen et al. 2012). Severely Fusarium-damaged wheat is typically characterized by thin or shrunken chalk-like kernels. Infected grains are poorly filled and may be blown out the back of the combine due to their low kernel weight. Grain infected after the flowering stage, however, may be heavy enough to be harvested along with healthy grain. After harvest, the quality of durum wheat may be evaluated from more than one point of view: agronomical quality, milling quality, technological quality, and hygienic and sanitary quality, which are related to damage to the grain or contamination with secondary metabolites (Beccari et al. 2017; Gilbert and Tekauz 2000; McMullen et al. 2012).

The reduced quality of Fusarium-damaged kernels (FDKs). Durum wheat, with hard, intensely yellow pigmented endosperm makes high quality pasta and increases the efficiency of semolina production (Ficco et al. 2014). Grain harvested from FHB-affected spikes is often shriveled and may have a red or yellow discoloration due to the presence of fungal growth (Martin et al. 2017). FHB also has adverse effects on semolina milling, gluten strength, and pasta color (Dexter and Edwards 1998). Dexter et al. (1997) evaluated 10 durum wheat cultivars for semolina milling and pasta-making quality that were downgraded, primarily because of FDKs. They reported that FDKs have a negative impact on kernel weight and test weight, resulting in lower semolina yield. Semolina ash content and bran specks were not affected by FDKs, but the semolina became duller and redder (Dexter et al. 1997). Additionally, they indicated that FDK had no effect on protein content, but gluten strength was weaker due to lower glutenin concentration (Dexter et al. 1997; Shahin et al. 2012). Therefore, pasta quality and not the texture was affected by FDK.

Mycotoxin contamination in FDK. In addition to direct yield losses caused by FHB, indirect losses due to the contamination of infected kernels with Fusarium mycotoxins is also highly problematic because they render the grain unfit for food and feed (Covarelli et al. 2015). The most widely found mycotoxin on cereal grains infected with FHB is the type B-trichothecene DON, primarily produced by $F$. graminearum (Wegulo 2012). Although environmentally dependent, generally, the higher the FDK the higher the level of mycotoxin, making FDK a grading factor. For example, in 
Canada, grades 1 and 2 of Canada Western Amber Durum permit only up to $0.5 \%$ FDK, while grades 3 and 4 allow up to $2 \%$, and grade 5 up to $4 \%$ (Canadian Grain Commission 2018).

Although food processing operations (milling and thermal processing) may reduce mycotoxin levels in agricultural commodities, they typically are not able to completely eliminate them from finished foods (Bullerman and Bianchini 2007). Cleaning and milling grain reduces overall microbial loads and DON concentration (Manthey et al. 2004). The DON level is reduced during durum wheat processing and spaghetti cooking. A consistent reduction of DON levels ranging from $77 \%$ in cleaned wheat, to $37 \%$ in semolina, $33 \%$ in freshly processed spaghetti, and $20 \%$ in cooked spaghetti occurred in samples of durum wheat contaminated with DON under field conditions (Visconti et al. 2004). During the milling process toxin contaminants are differentiated between the bran and the endosperm fractions, with higher loads of toxins associated with the bran, as opposed to the endosperm (Berghofer et al. 2003), which may lead to an increased risk of toxin contamination in whole grain pasta products.

Some countries have set regulations for permissible levels of mycotoxins in unprocessed and processed foods. For example, the European Commission Regulation of 2007 has set the maximum permitted level for DON in cereal-based foods for infants and children, as well as cereals intended for direct human use and finished wheat products for human consumption at $0.20,0.75$, and $1.00 \mathrm{ppm}$, respectively (European-Commission 2007). In Canada, wheat-based foods contribute most of the DON exposure (80 to $90 \%)$, followed by oats $(<5 \%)$. Thus, maximum limits for DON of 1 to 2 ppm in flour, meal, semolina, and flakes derived from wheat have been proposed by Heath Canada (under review), depending on the product use (Health Canada 2016). The U.S. Food and Drug Administration (FDA) has also established guidance or action levels for DON in unprocessed and processed foods, which range from $1 \mathrm{ppm}$ to $30 \mathrm{ppm}$ depending on the use (FDA 2016). Therefore, the loss of foodstuffs due to mycotoxin contamination alone is estimated to be 1 billion tons per year (Thielecke and Nugent 2018). Losses from rejection of food commodities lead to sale of the contaminated products at lower prices in the local markets, which might result in higher mycotoxin exposure in low-income communities in countries where DON is not regulated (Ashiq 2015).

Although DON is the only regulated mycotoxin produced by F. graminearum, the presence of other secondary metabolites and their impact on toxicity of DON may change the regulatory landscape. Therefore, food safety considerations require a wideranging discussion on the need to update legislation concerning the threshold of other metabolites in food products, given the fact that other toxins, including DON derivatives, commonly accompany DON (Bryła et al. 2019).

\section{RESEARCH EFFORTS FOR FHB RESISTANCE IN DURUM WHEAT}

There is no bread or durum wheat cultivar released to market with complete resistance or immunity to FHB. This is partly because resistance to FHB is a complex and quantitatively inherited trait controlled by multiple genes and affected by environmental factors (Bai and Shaner 1994), all of which lead to slow genetic gain per unit time (Dweba et al. 2017). Genetic resistance is the most cost effective and environmentally safe method for controlling FHB (Shah et al. 2018; Steiner et al. 2017), and development of cultivars with improved resistance is a major goal of wheat breeding programs globally (Rosewarne et al. 2008). Compared with bread wheat, less efforts have been dedicated to improve FHB resistance in durum wheat, possibly due to smaller acreage and fewer breeding programs (Buerstmayr et al. 2009), and to historic distribution of durum production in semiarid environments where FHB was not a major problem. Breeding progress appears hampered by the relatively narrow genetic variation for FHB resistance in durum wheat elite germplasm (Prat et al. 2017). In addition, in recent years, the lack of precise knowledge on the genetic factors governing FHB resistance has placed a major stumbling block on breeding efforts implemented for the genetic improvement of this trait in durum (Giancaspro et al. 2016). But on the other hand, the availability of high-density consensus maps (Maccaferri et al. 2015), reference genomes (Maccaferri et al. 2019) and pan genomes for tetraploid wheat may facilitate genetic analysis of FHB resistance, including QTL mapping, marker discovery and cloning of resistance genes in durum wheat. In addition, it will also help to uncover how wheat can best defend itself against FHB fungi. For example, in our wheat breeding programs at the University of Saskatchewan, we are using the latest sequencing and assembly technologies to generate several whole genome assemblies for tetraploid wheat, with the goal to uncover the genetic cause of important complex traits in durum wheat, including resistance to FHB.

QTL mapping and genome-wide association studies for FHB resistance. Linkage analysis and association mapping are two of the most common approaches for QTL mapping. The recent availability of linkage maps based on abundant DNA markers has vastly improved the ability to identify and characterize such QTL (Giancaspro et al. 2016; He et al. 2016). The main purposes of QTL mapping are the identification of markers closely linked to the trait of interest, FHB resistance, and the application of these markers for marker assisted selection (MAS) (He et al. 2018). In addition, QTL mapping and fine mapping lay the foundation for eventually cloning of the underlying resistance genes, which provides a better understanding of resistance mechanisms (He et al. 2018).

Numerous QTL for FHB resistance were reported in bread wheat, whereas only a limited number of small-effect QTL for FHB resistance have been identified in tetraploid wheats (Buerstmayr et al. 2014; Prat et al. 2014). Compared with the major resistance QTL ( $F h b 1$, which contribute 25 to $41.6 \%$ of the resistance to FHB) identified in bread wheat (Anderson 2007; Buerstmayr et al. 2003; Liu and Anderson 2003), effects of FHB resistance QTL detected in tetraploid wheat are relatively small $(<12 \%)$ (Giancaspro et al. 2016; Prat et al. 2014; Zhao et al. 2018). Most of the durum wheat populations mapped so far were based on exotic genetic resources from resistant donors (Prat et al. 2014, 2017). However, use of exotic sources requires several backcrosses and additional cycles of recurrent selection to obtain high-yielding and market-acceptable durum cultivars. In other words, it is a time-consuming process to incorporate resistance from nonadapted germplasm, particularly wild relative species, into elite durum lines or varieties due to linkage drag and competition drag (Prat et al. 2014). Therefore, a more straightforward strategy is to use adapted durum breeding populations to improve FHB resistance where possible (Miedaner et al. 2017). Unfortunately, this is also challenging as genetic variation in the primary gene pool seems narrow (Buerstmayr et al. 2014) and most modern cultivars are highly susceptible to FHB (Clarke et al. 2010; Miedaner and Longin 2014; Prat et al. 2014; Zhao et al. 2018).

The review of Prat et al. (2014) addressed the genetic basis of FHB resistance derived from durum wheat and its relatives; thus, this current review mostly highlights FHB resistance loci published after 2014. Approximately 13 QTL for FHB resistance with small to moderate effects were repeatedly detected on 11 of the chromosomes of tetraploid wheat (Buerstmayr et al. 2012, 2013; Chen et al. 2007; Ghavami et al. 2011; Gladysz et al. 2007; Kumar et al. 2007; Otto et al. 2002; Ruan et al. 2012). Since 2014, there have been several new studies that have identified FHB resistance QTL derived from tetraploid wheat. Recently, Sari et al. (2018) reported resistance QTL on chromosomes 1A and 5A that are consistently expressed over multiple environments using two doubled haploid (DH) populations, one developed from a cross between DT707 and 
DT696 and the other between Strongfield durum and T. turgidum subsp. carthlicum 'Blackbird'.

Many of the QTL identified above result in reduced fungal spread past the point of infection; however, the underlying mechanisms are not well characterized. It is known that DON likely acts as a virulence factor and assists in fungal spread beyond the site of infection (Jansen et al. 2005). Two QTL for resistance to FHB were identified on chromosomes $1 \mathrm{~B}$ and $4 \mathrm{~B}$ using a backcross recombinant inbred line (BCRIL) tetraploid wheat population (Ruan et al. 2012). A recent study by $\mathrm{Li}$ et al. (2017) showed a barley UDPglucosyltransferase that efficiently detoxified DON, and when expressed in transgenic wheat resulted in reduced fungal spread for DON-producing $F$. graminearum and moreover, modified nivalenol (NIV) to the nontoxic NIV glucoside. Additional research is required to determine if similar mechanisms are behind some of the resistance QTL identified in durum wheat studies. Nevertheless, finding effective sources of DON resistance and developing DNA markers associated with the resistance QTL are of top priority in durum wheat breeding programs.

In addition to using tetraploid sources of FHB resistance in durum breeding, it is also possible to use intergeneric crosses with bread wheat. Bread wheat and durum wheat share the A and B genomes and diagnostic markers for $F h b 1$ and other FHB resistant loci are known; therefore, introgression of these QTL from bread wheat into durum wheat is possible. More recently, reports have demonstrated a successful transfer of FHB resistance from bread wheat into durum lines, including Fhbl (Giancaspro et al. 2016; Prat et al. 2017; Zhao et al. 2018). Prat et al. (2017) developed three biparental populations by crossing line DBC-480, an FHB-resistant experimental durum line possessing the $F h b 1$ allele from 'Sumai 3' (FHB-resistant Chinese cultivar), with a modern European durum breeding line and two current durum cultivars. In these populations, Fhbl led to significant reduction in fungal colonization of the host in point-inoculated greenhouse tests and a reduction in FHB severity under spray-inoculated field conditions of 6,30 , and $36 \%$ in the three populations. In addition to $F h b 1$, other resistance QTL were also detected on chromosomes 2A, 2BL, 4AL, 4BS, 5AL, and 6AS (Prat et al. 2017). The efficient introgression of Fhb1 into durum represents a major achievement in resistance breeding and to the development of the novel resistant germplasm in durum wheat breeding. Similarly, the major QTL Qfhb.ndwp-5A and Qfhb.ndwp$7 A$ from the bread wheat line PI 277012 were successfully introgressed into local durum cultivars (Zhao et al. 2018), which represents another significant step toward using bread wheat sources to enhance FHB resistance in durum. Furthermore, the 5AL, 2A, and 7A QTL in PI 277012 are other effective resistance sources from bread wheat that might be used to develop durum wheat cultivars with improved FHB resistance (Zhao et al. 2018). In a separate study, major QTL on chromosomes $2 \mathrm{AS}$ and $3 \mathrm{AL}$ for FHB incidence and on 2AS, 2BS, 4BL for severity were mapped using a durum recombinant inbred line (RIL) population obtained by crossing Sumai-3 with the durum wheat cultivar Saragolla (Giancaspro et al. 2016).

In a genome-wide association study by Miedaner et al. (2017), the $R h t-B l b$ dwarfing allele significantly affected $\mathrm{FHB}$ resistance and eight additional QTL (2B, 3A, 3B, 4A, 4B, 5A, 5B, and 7A) were identified where the proportion of genotypic variance $(\mathrm{pG})$ explained by these QTL varied from 1 to $14 \%$. The highest $\mathrm{pG}$ was observed for $R h t-B 1$, for which the wild-type Rht-B1a allele improved FHB resistance by 0.9 severity points on the 1 to 9 scale. On the other hand, lines with the dwarfing allele $R h t-B 1 b$ ranged in mean FHB severity from 3.4 to 6.3. In an international collection of durum wheat cultivars, Steiner et al. (2019) identified colocalization of plant height and resistance QTL to other FHB resistance QTL on chromosomes 1A, 2A, 2B, 3B, 4B, 5A, 6A, and 6B.

The QTL found in tetraploid wheat populations largely overlap with the QTL identified in bread wheat, suggesting a common genetic basis of FHB resistance (Prat et al. 2014; Tuberosa and Pozniak 2014). However, the QTL detected in tetraploid wheat have so far failed to provide a level of resistance comparable to that of Fhbl in bread wheat. In bread wheat, the Sumai 3-derived resistance allele $F h b 1$ has been used extensively due to its relatively consistent major effect on type II resistance, and shows promise in durum wheat as well (Prat et al. 2017), but is not sufficient to control FHB alone under moderate to high disease pressure. Therefore, it is of utmost importance to look for additional sources of resistance to enlarge the genetic diversity of FHB resistance for the durum gene pool. A list of already described durum germplasm and lines potentially useful to improve FHB is given in Table 1.

Genomic prediction for FHB resistance. Numerous association mapping studies have been performed in bread wheat germplasm (Arruda et al. 2016a; Mirdita et al. 2015a, b; Tessmann and Van Sanford 2018; Wang et al. 2017) and fewer in durum wheat (Miedaner et al. 2017; Steiner et al. 2018). Most of these studies confirmed that FHB resistance is a complex trait controlled by many interacting loci with epistatic effects; therefore, genomic selection (GS) may be an attractive option for selecting for resistance in breeding programs. MAS for complex traits can be challenging when multiple loci are involved, that is why breeders often turn to phenotypic selection; however, advances in high-throughput genotyping provide extensive genome-wide marker information and GS is becoming an emerging alternative to phenotypic selection of complex traits. Genomic selection exploits both linkage disequilibrium (LD) between dense markers and "all" the QTL associated with a trait. Through estimating marker effects for all marker variants (Meuwissen et al. 2001) in a large and representative training population (TP), GS has the potential to capture the majority of genetic variance for a trait that is modulated by many small effect QTL (Mirdita et al. 2015b; Rutkoski et al. 2017). From previous classical and molecular genetic studies, it is known that genetic variation for FHB resistance is predominantly additive (Bai et al. 2000), indicating that accumulation of resistance alleles may be possible (Poland and Rutkoski 2016). The combination of this quantitative inheritance coupled with a complex phenotype makes resistance to FHB an excellent target for GS approaches (Poland and Rutkoski 2016). In addition, phenotyping FHB susceptibility and mycotoxin levels is laborious and expensive. For example, phenotyping for severity and incidence of FHB requires plant inoculation and visual monitoring of symptoms over a short window during anthesis in carefully managed disease nurseries or controlled greenhouses/growth cabinets. Likewise, DON phenotyping requires access to expensive analytical chemistry instruments, such as gas and liquid chromatography, or testing kits, such as enzyme-linked immunosorbent assays. Therefore, applying GS for FHB resistance breeding enables more breeding candidates to be evaluated at lower cost, allowing for higher selection intensity, as opposed to phenotypic selection where there is a limit to the number of entries one can evaluate in a disease nursery (Poland and Rutkoski 2016). In addition, selection can be performed ahead of cost-intensive phenotypic tests, allowing for preselection of the most promising lines for the expensive phenotypic evaluations (Crossa et al. 2010; Poland et al. 2012).

A number of empirical and theoretical studies suggest that GS could increase genetic gain per unit of time beyond what is possible with phenotypic selection (Heffner et al. 2010; Heslot et al. 2014; Meuwissen et al. 2001), mainly by shortening the lengths of breeding cycles (Sallam et al. 2015). Several authors report on evaluation of GS approaches for predicting FHB in bread wheat. The earliest paper by Rutkoski et al. (2012) evaluated different GS models for FHB resistance and gave the first evidence that GS prediction models have accuracy high enough to be useful in breeding. Arruda et al. (2015) confirmed that the traits associated with FHB resistance, including incidence, severity, and DON levels, are predictable with moderate to high accuracy. Jiang et al. (2014) 
TABLE 1

List of potential Fusarium head blight (FHB)-resistant lines used to improve FHB resistance in durum wheat

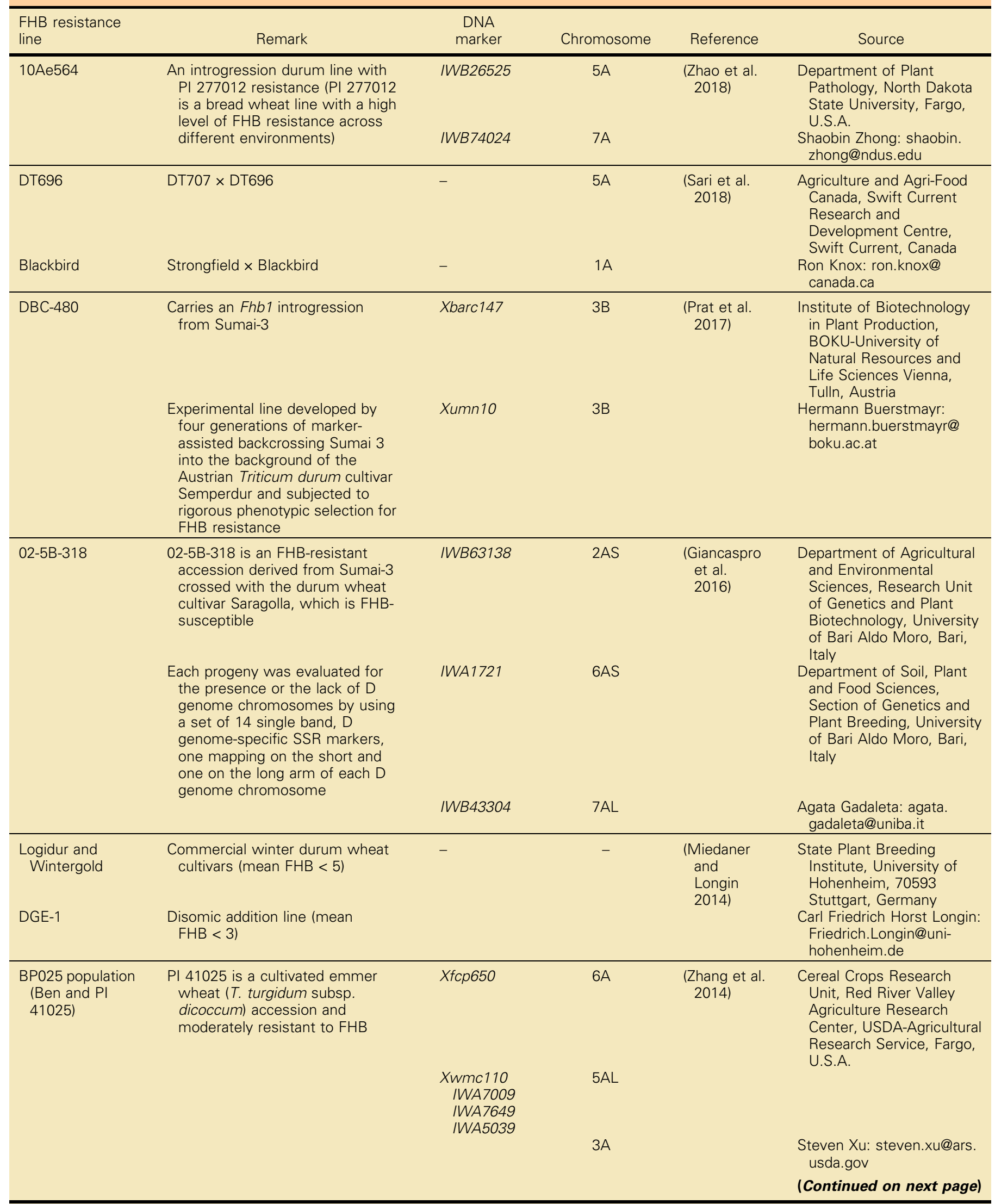


TABLE 1

(Continued from previous page)

\begin{tabular}{|c|c|c|c|c|c|}
\hline $\begin{array}{l}\text { FHB resistance } \\
\text { line }\end{array}$ & Remark & $\begin{array}{l}\text { DNA } \\
\text { marker }\end{array}$ & Chromosome & Reference & Source \\
\hline Mt. Gerizim \#36 & $\begin{array}{l}\text { Moderate FHB resistance and is a } \\
\text { hulled wheat with brittle rachis, } \\
\text { has a short and awned spike } \\
\text { phenotype, tough glumes, and is } \\
\text { tall and sensitive to lodging }\end{array}$ & Xgwm133 & $6 \mathrm{~B}$ & $\begin{array}{l}\text { (Buerstmayr } \\
\text { et al. } \\
\text { 2013) }\end{array}$ & $\begin{array}{l}\text { Institute of Biotechnology } \\
\text { in Plant Production, } \\
\text { BOKU-University of } \\
\text { Natural Resources and } \\
\text { Life Sciences, Vienna, } \\
\text { Tulln, Austria } \\
\text { Hermann Buerstmayr: } \\
\text { hermann.buerstmayr@ } \\
\text { boku.ac.at }\end{array}$ \\
\hline Td161 & $\begin{array}{l}\text { By crossing with three susceptible } \\
T \text {. durum wheat cultivars, three } \\
\text { populations segregating for FHB } \\
\text { resistance were generated }\end{array}$ & Xbarc133 & $x^{2}$ & $\begin{array}{l}\text { (Buerstmayr } \\
\text { et al. } \\
\text { 2012) }\end{array}$ & $\begin{array}{l}\text { Institute of Biotechnology } \\
\text { in Plant Production, } \\
\text { BOKU-University of } \\
\text { Natural Resources and } \\
\text { Life Sciences, Vienna, } \\
\text { Tulln, Austria } \\
\text { Hermann Buerstmayr: } \\
\text { hermann.buerstmayr@ } \\
\text { boku.ac.at }\end{array}$ \\
\hline $\begin{array}{l}\text { Tun18 } \\
\text { Tun36 } \\
\text { Tun108 } \\
\text { Tun134 }\end{array}$ & $\begin{array}{l}\text { Tetraploid wheat sources of } \\
\text { resistance from Tunisia, which } \\
\text { were selected among many lines } \\
\text { evaluated over five repeated } \\
\text { FHB trials }\end{array}$ & $\begin{array}{l}\text { WPt-0054 } \\
\text { wPt-7279 } \\
\text { wPt-2885 } \\
\text { wPt-6910 }\end{array}$ & $\begin{array}{l}5 B \mathrm{BL} \\
5 \mathrm{BL} \\
5 \mathrm{BL}\end{array}$ & $\begin{array}{l}\text { (Ghavami } \\
\text { et al. } \\
\text { 2011; } \\
\text { Huhn et al. } \\
\text { 2012) }\end{array}$ & $\begin{array}{l}\text { North Dakota State } \\
\text { University, Department of } \\
\text { Plant Sciences, Fargo, } \\
\text { U.S.A. } \\
\text { Shahryar Kianian: s. } \\
\text { kianian@ndsu.edu } \\
\text { Elias Elias: elias.elias@ } \\
\text { ndsu.edu }\end{array}$ \\
\hline Divide & $\begin{array}{l}\text { North Dakota State University } \\
\text { cultivar and partially resistant } \\
\text { Selected from the cross 'Ben' } \\
\text { (PI596557)/D901282//'Belzer' } \\
\text { (PI 603286) } \\
\text { Tunisian landrace (tall, late } \\
\text { maturing, and adapted to } \\
\text { drought-prone growing } \\
\text { conditions) }\end{array}$ & - & - & $\begin{array}{l}\text { (Fakhfakh } \\
\text { et al. } \\
\text { 2011) }\end{array}$ & $\begin{array}{l}\text { Laboratory of Plant } \\
\text { Breeding, National } \\
\text { Agronomy Institute of } \\
\text { Tunis (INAT), Tunis- } \\
\text { Mahrajene, Tunisia } \\
\text { M. Fakhfakh: fmedmoez@ } \\
\text { yahoo.fr } \\
\text { North Dakota State } \\
\text { University, Department of } \\
\text { Plant Sciences, Fargo, } \\
\text { U.S.A. } \\
\text { Shahryar Kianian: s. } \\
\text { kianian@ndsu.edu }\end{array}$ \\
\hline Mt. Hermon \#22 & $\begin{array}{l}\text { Wild emmer wheat line from the } \\
\text { collection of the Institute of } \\
\text { Evolution, University of Haifa, } \\
\text { Israel }\end{array}$ & $\begin{array}{l}\text { Xbarc167 } \\
\text { Xs13m20-5 } \\
\text { Xgwm375 }\end{array}$ & $\begin{array}{l}4 \mathrm{~A} \\
2 \mathrm{~B} \\
4 \mathrm{~B}\end{array}$ & $\begin{array}{l}\text { (Gladysz } \\
\text { et al. } \\
\text { 2007) }\end{array}$ & $\begin{array}{l}\text { Institute of Biotechnology } \\
\text { in Plant Production, } \\
\text { BOKU-University of } \\
\text { Natural Resources and } \\
\text { Life Sciences, Vienna, } \\
\text { Tulln, Austria } \\
\text { Hermann Buerstmayr: } \\
\text { hermann.buerstmayr@ } \\
\text { boku.ac.at }\end{array}$ \\
\hline $\begin{array}{l}123 \text { recombinant } \\
\text { inbred lines } \\
\text { (RILs) } \\
\text { Euploid LDN } \times \\
\text { PI478742 7A) }\end{array}$ & $\begin{array}{l}\text { Langdon (LDN) that has a pair of } \\
\text { T. turgidum sp. dicoccoides } \\
\text { PI478742 7A chromosomes } \\
\text { substituted for the native 7A } \\
\text { chromosomes (LDN-DIC 7A) }\end{array}$ & $\begin{array}{l}\text { (detected a } \\
210-b p \\
\text { fragment in } \\
\text { LDN, may } \\
\text { be of use } \\
\text { for MAS) }\end{array}$ & $7 \mathrm{~A}$ & $\begin{array}{l}\text { (Kumar } \\
\text { et al. } \\
\text { 2007) }\end{array}$ & $\begin{array}{l}\text { North Dakota State } \\
\text { University, Department } \\
\text { of Plant Sciences, Fargo, } \\
\text { U.S.A. } \\
\text { J. D. Faris: farisj@fargo.ars. } \\
\text { usda.gov }\end{array}$ \\
\hline
\end{tabular}




\section{TABLE 1}

(Continued from previous page)

\begin{tabular}{|c|c|c|c|c|c|}
\hline $\begin{array}{l}\text { FHB resistance } \\
\text { line }\end{array}$ & Remark & $\begin{array}{l}\text { DNA } \\
\text { marker }\end{array}$ & Chromosome & Reference & Source \\
\hline \multirow[t]{2}{*}{$\begin{array}{l}83 \text { recombinant } \\
\text { inbred } \\
\text { chromosome } \\
\text { lines (RICL) } \\
\text { individuals }\end{array}$} & $\begin{array}{l}\text { They are in a 'Langdon-16' durum } \\
\text { background }\end{array}$ & Xgwm2 & $3 \mathrm{~A}$ & $\begin{array}{l}\text { (Otto et al. } \\
\text { 2002) } \\
\text { (Chen et al. } \\
\text { 2007) }\end{array}$ & $\begin{array}{l}\text { University of Minnesota, } \\
\text { Department of Agronomy } \\
\text { and Plant Genetics, } \\
\text { St. Paul, U.S.A. } \\
\text { C. D. Otto: otto0099@umn. } \\
\text { edu }\end{array}$ \\
\hline & $\begin{array}{l}\text { The resistant RICLs that contain } \\
\text { the smallest T. dicoccoides } \\
\text { fragments harboring Qfhs.ndsu- } \\
3 A S \text { will be useful for the } \\
\text { introgression of this resistance } \\
\text { quantitative trait locus to } \\
\text { adapted wheat backgrounds }\end{array}$ & Xfсp397.2 & & & $\begin{array}{l}\text { Department of Plant } \\
\text { Sciences, North Dakota } \\
\text { State University, Fargo, } \\
\text { U.S.A. } \\
\text { Xiwen Cai: xiwen.cai@ } \\
\text { ndsu.edu }\end{array}$ \\
\hline $\begin{array}{c}\text { FA-15-3 (syn. } \\
\text { 'Israel A') }\end{array}$ & T. dicoccoides accession & Xgwm2 & $3 A$ & $\begin{array}{l}\text { (Ban and } \\
\text { Watanabe } \\
\text { 2001) }\end{array}$ & $\begin{array}{l}\text { Japan International } \\
\text { Research Center for } \\
\text { Agricultural Sciences } \\
\text { (JIRCAS), Tsukuba, } \\
\text { Japan }\end{array}$ \\
\hline
\end{tabular}

and Mirdita et al. (2015a) tested the potential and limits of GS for predicting FHB resistance in European winter wheat populations and confirmed that it is a promising improvement tool. Recently, Arruda et al. (2016b) compared MAS and GS models using a panel of 273 soft red winter wheat lines and found intermediate to high values of prediction accuracy for GS models and lower values for MAS, indicating that GS is a more appropriate strategy than MAS for FHB resistance. Bassi et al. (2016) provided key considerations when implementing GS in durum wheat breeding and Poland and Rutkoski (2016) summarized studies exploring GS models for predicting FHB in wheat. Miedaner et al. (2017) evaluated the potential of GS approaches for the improvement of FHB resistance in an international panel of 170 winter and 14 spring durum lines. According to these authors, the genome-wide prediction approach yielded only a slightly improved predictive ability compared with MAS using the four markers linked with loci 2B, 4B, 5B and 7B which explained more than $5 \%$ of the genotypic variance for $\mathrm{FHB}$ resistance. Similarly, Steiner et al. (2018) assessed a worldwide collection of 228 genotyped durum wheat cultivars and lines for FHB resistance over 3 years to explore the prospective of genomicassisted breeding for FHB resistance in durum wheat. They reported that phenotypic selection for FHB resistance revealed a superior prediction ability over genomic prediction. On the other hand, GS has been demonstrated to be a very promising breeding strategy for FHB resistance in winter wheat (Arruda et al. 2015; Mirdita et al. 2015b) and recently in spring wheat (Dong et al. 2018).

Developing a meaningful GS strategy requires investment in genotyping, thorough phenotyping of a training population that is closely related to the breeding population, as well as careful consideration of GS models that account for genetic architecture. For example, when the true genetic architecture is largely or partially due to epistatic interactions, the additive model may not perform well, while models that account explicitly for interactions generally increase prediction accuracy. The full advantage of GS becomes evident when GS is already implemented in a breeding program for enhancing selection gain for economically important traits, such as grain yield and quality. In this case, genotypes and phenotypes are already generated for this purpose and additional phenotyping of the training population for FHB resistance allows the generation of prediction models for FHB resistance at relatively low cost. One limitation of using GS for FHB resistance is that it is only possible to select a similar level of resistance that is observed in the training population, which will not assist in the selection of transgressive lines with improved resistance, but it may be suitable for culling lines with high susceptibility. An example of GS scheme for testing GS models and assessing accuracy for FHB resistance is presented in Figure 1. Once accurate modeling for FHB resistance is set using the training population, it is possible to use GS to predict the FHB reaction in the F5 lines instead of phenotyping them in the FHB nursery, thus allowing F4 head rows to proceed directly to preliminary yield trials. This would lead to a savings of 2 years in the cultivar development pipeline, as well as assist in the selection of parents for further crossing.

Morphological traits as potential resources to improve FHB resistance of durum wheat. Certain morphological and phenological traits of wheat have been associated with FHB resistance. Although the effects of plant height on resistance is less clear, tall cultivars tend to show reduced signs of disease initiation. Plant height and resistance to FHB are negatively correlated in bread wheat (Draeger et al. 2007; Srinivasachary et al. 2009; Yan et al. 2011) and durum wheat (Buerstmayr et al. 2012; Giancaspro et al. 2016; Steiner et al. 2018) due to a negative relationship between some (semi)dwarfing alleles and resistance to FHB. Particularly considering the increased FHB susceptibility of plants carrying the gibberellic acid (GA) insensitive Rht-1b alleles, it is now of utmost interest to use GA sensitive dwarfing loci to achieve shorter plants. For example, Rht 24 does not significantly affect FHB severity (Herter et al. 2018) unlike the Rht-1 semidwarfing alleles. Therefore, the choice of semidwarfing genes used in wheat breeding programs is of highest consideration where resistance to FHB is an essential breeding target.

In addition to plant height, days to heading, anther extrusion, and head compactness may also have a role in FHB resistance. McCartney et al. (2016) reported that QTL for FHB resistance were generally independent of QTL for anthesis date or plant height; in contrast, resistance to initial infection coincided with QTL for days to heading and anther extrusion in a study by $\mathrm{He}$ et al. (2016). This may indicate that environmental or genetic factors may be affecting the interplay between these traits. This is supported by studies which show that the extent of anther retention after 
flowering and FHB severity may be positively associated with the semidwarfing allele Rht-D1b (Buerstmayr and Buerstmayr 2016; Steiner et al. 2017). In fact, high level of anther extrusion has been suggested as a very useful indirect selection criterion to improve FHB resistance (Buerstmayr and Buerstmayr 2015, 2016; Steiner et al. 2017); though variation for this trait in modern durum wheat seems low, durum cultivars often exhibit a high level of anther retention. Like anther retention, a positive correlation between FHB incidence and severity with spike compactness was reported in a durum wheat population tested over three environments, which may also be related to genes involved in plant height (Giancaspro et al. 2016).

Emerging evidence also indicates that content and composition of cell wall polymers affect the susceptibility of the cell wall to degrading enzymes produced by pathogens during infection and can play a role in the outcome of host-pathogen interactions (Bellincampi et al. 2014; Pogorelko et al. 2013). Cell wallassociated defense appears to operate via inhibition of fungal cell wall--degrading enzymes, secretion of fungitoxic peptides and phytoalexins, and cell wall strengthening. Lionetti et al. (2015) identified potential cell wall biochemical traits linked to FHB resistance when transferring resistance from a bread wheat line to a susceptible durum line. They did a detailed analysis of cell wall composition in spikes isolated from 02-5B-318, a highly resistant bread wheat accession derived from 'Sumai 3', and susceptible durum cultivar Saragolla and found significant differences in lignin monolignol composition, arabinoxylan substitutions and pectin methylesterification between resistant and susceptible plants. Additionally, they isolated and characterized a pectin methylesterase gene WheatPME1, which is down-regulated in the FHBresistant line and induced by fungal infection in the susceptible line. These cell wall traits provide insights into the mechanism by which wheat is able to defend itself against Fusarium. It would be interesting to determine if the mechanism of resistance is similar in other FHB-resistant germplasm, which could be tested using cell wall components as biomarkers or WheatPME1 as an expression-based marker. Such markers could also be used as selection targets in FHB breeding programs, but may be impractical for large-scale screens.

\section{CHARACTERIZATION OF GENES AND PATHWAYS INVOLVED IN FHB RESISTANCE}

Since FHB resistance is a quantitative trait, it can be difficult to identify the genes responsible for resistance and characterize their mechanism. Identification of FHB resistance has largely focused on minor QTL with variable expression across environments and therefore fine mapping and identification of genes is difficult. The absence of major resistance genes may be attributed to the lifestyle of the fungus, which begins biotrophically and becomes necrotrophic as the disease progress (Ding et al. 2011). As a result, major effect gene-for-gene interactions that result in a hypersensitivity response or cell death, as observed for many biotrophic rust fungi (Periyannan et al. 2017), have not been identified for FHB and are likely to be ineffective against $F$. graminearum.

Since the mechanisms of FHB detection and downstream defense are not well understood, characterization of genes involved in pathogen recognition and nonhost resistance may be a good starting point. Initial plant defense pathways, based on the detection of $F$. graminearum by pathogen recognition receptors, are likely to play a role in triggering the interaction between the host and the pathogen (Jones and Dangl 2006), but the receptors involved are largely unexplored.

With the recent release of the genome of durum wheat (Maccaferri et al. 2019), we now have a physical map of the durum wheat genome that can be used characterize the network of genes involved in FHB resistance and susceptibility (van Schie and Takken 2014). Receptors for $F$. graminearum recognition can be identified based on orthology to known receptors or based on receptor expression during $F$. graminearum infection, as in Thapa et al. (2018). Gene expression studies comparing resistant and susceptible germplasm can also help unify a model that includes known defense response receptors, defense signaling pathways, common defense pathways, and their interaction with morphological traits, such as cell wall composition, plant height, days to heading, anther extrusion, and head compactness. By physically anchoring QTL to the available genome sequences of Svevo and Zavitan, candidate resistance or susceptibility genes can now be identified and then characterized through functional genetics studies, such as CRISPR-Cas9 gene-editing or targeted mutagenesis, which will then validate components of the defense response network. Until now, the identification and characterization of FHB resistance genes has been slow; however, we are now entering a new era of functional genomics where we can begin to uncover how wheat defends itself against FHB.

Mutagenesis for FHB resistance breeding. Breeding for FHB resistance in wheat has been hindered by a lack of available genetic variation within existing germplasm resources, particularly in durum wheat. One strategy to generate new genetic variation is to apply mutagenesis strategies to generate novel alleles that may be useful in breeding. Improvement of FHB resistance and characterization of candidate resistance genes in durum wheat can be performed by random mutagenesis or gene-editing; however, the latter remains controversial in the context of breeding (Callaway

\section{FIGURE 1}

Example of genomic selection scheme for Fusarium head blight (FHB) resistance. Parents are crossed and give rise to the F1 generation. F1 plants are self-pollinated giving rise to the F2 and continue to be planted until F4. F4 plants are genotyped, their genomic estimated breeding values for FHB and all traits of interest are predicted, and new parents

for crossing are also identified. Seed from F4 plants are harvested separately, giving rise to the F4:F5 generation. The F4:F5 population is planted in an FHB nursery and the breeder can select top individuals and simultaneously the phenotypic and genotypic data are used for model validation. Selected inbred lines from each plot are harvested to advance to F4:F6 and F4:F7 generations where potential candidates will be entered in the advanced trials to be evaluated for grain yield, agronomic traits and end-use quality tests and further to cultivar release. Genotypic and phenotypic data on the new germplasm should enter the training population to update the prediction model.

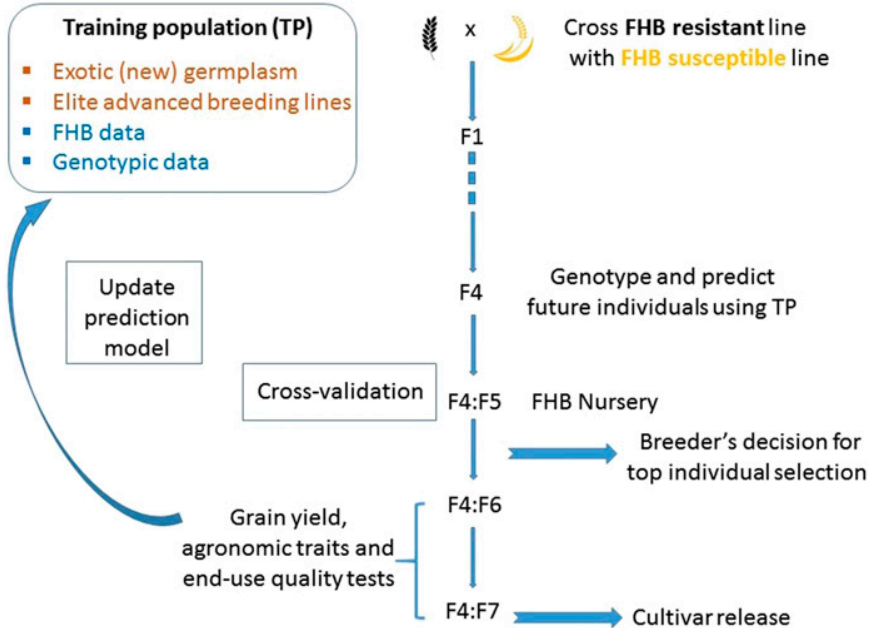

Vol. 109, No. 10, 2019 1671 
2018). Mutation breeding involves the induction of heritable genetic mutations through physical (X-rays, ion beam, or gamma rays) or chemical approaches (ethyl methanesulfonate [EMS]). Because similar mutations can also occur naturally, mutation breeding does not suffer from the same regulatory concerns as genome edited crops. The first step in mutagenesis breeding in wheat typically begins with the application of a chemical or physical mutagen to the seed, which is subsequently planted, representing the M1 generation. The M1 generation is self-pollinated to obtain M2 embryos, and phenotypic or genetic screening can be performed beginning at the M2 generation. Mutagenesis has been used in wheat to develop altered gluten proteins (Köksel et al. 1998), altered amylose or resistant starch composition (Mishra et al. 2016; Slade et al. 2005), and improve resistance to multiple biotrophic fungal pathogens (Campbell et al. 2012). Screening of mutant populations can be performed through reverse genetic approaches, which is the underlying strategy for detecting mutations through the commonly used Targeting Induced Local Lesions IN Genomes (TILLING) approach (McCallum et al. 2000). TILLING relies on the use of EMS as a chemical mutagen, which primarily induces $\mathrm{C} / \mathrm{G}$ to $\mathrm{T} / \mathrm{A}$ point mutations (McCallum et al. 2000), although larger scale deletions have also been reported in wheat (Henry et al. 2014).

Detection of mutations is now routinely done using nextgeneration sequencing approaches. In wheat, TILLING resources have now been established for tetraploid cultivar Kronos and hexaploid cultivar Cadenza (Krasileva et al. 2017). Reverse genetic approaches like TILLING have been integral to FHB researchers aiming to perform functional validation of resistance genes and pathways, including the discovery of the candidate gene for $F h b 1$ (Rawat et al. 2016). FHB breeding may also benefit from forward phenotypic screening of mutant populations, a strategy that aims to capitalize on the loss-of-function of potential susceptibility factors. The benefit to this approach is that no a priori knowledge about the underlying genes and resistance pathways is required. In addition, selection of the parental cultivar for mutagenesis is flexible and can be performed on existing cultivars, or advanced breeding lines. In this approach, mutants would be selected under FHB infection based on resistance response in the field, greenhouse or growth chamber nurseries. Selections could then be advanced to later generations, screened in a wider range of environments and used for crossing in breeding programs.

\section{CONCLUSIONS AND FUTURE DIRECTIONS}

Fusarium head blight is a difficult disease to control; however, significant progress in understanding the pathogen, the genetics of resistance, epidemiology, and the development of strategies for FHB management has been achieved in the last 2 decades (Buerstmayr et al. 2009; Kazan et al. 2012; McMullen et al. 2012). Enhancing FHB resistance has proven difficult due to its polygenic nature (Kage et al. 2017), low heritability under normal field conditions, sporadic occurrence, and limited genetic variation for this trait in the durum wheat gene pool (Tuberosa and Pozniak 2014) compared with variation in bread wheat. Due to the smaller acreage and production quantity, less effort has been dedicated to improve FHB resistance in durum compared with bread wheat (Buerstmayr et al. 2009) even if moderately resistant germplasm is possible through introgression of Fhb1 from bread wheat into T. durum (Prat et al. 2017).

Further improvement in FHB resistance in durum wheat will be achievable through an accumulation of resistance QTL in breeding germplasm, similar to bread wheat. Genome-wide association mapping studies in durum have revealed QTL with mostly small effects (Miedaner et al. 2017), underlining the quantitative nature of FHB resistance. Additionally, QTL with medium effect were reported, mainly in more exotic genetic resources, such as
T. carthlicum (Sari et al. 2018), T. dicoccoides (Buerstmayr et al. 2013; Kumar et al. 2007; Otto et al. 2002; Ruan et al. 2012), and T. dicoccum (Buerstmayr et al. 2012; Zhang et al. 2014). Therefore, rapid phenotypic recurrent selection, ideally assisted by GS, may be a promising approach to improve this trait in durum.

The current method used by breeders to screen for FHB resistance in wheat germplasm involves phenotyping in the field or greenhouse based on a visual examination. This evaluation, subject to interpretation and requiring repeated observations, is incompatible with high-throughput phenotyping. Irrespective of selection method, precise and accurate phenotypes are the basis of any successful breeding for FHB resistance. Progress in the development of field-based high throughput phenotyping methods has advanced considerably in the last 10 years through technological progress in sensor development and high-performance computing (Shakoor et al. 2017). Thus, to facilitate the work of breeders, it is important to develop and implement a field phenotyping system that can improve FHB assessments of plots without damaging the plants, as well as efficiently and rapidly evaluating the resistance of these plants in the field.

The reduction of plant height is an important breeding goal in durum wheat and consequently the semidwarfing Rht- $B 1 \mathrm{~b}$ allele is now widespread in durum wheat breeding programs worldwide. Utilization of semidwarf alleles is, however, associated with some unwanted characteristics, including increased susceptibility to FHB. Therefore, the choice of semidwarfing genes used in durum wheat breeding programs is of highest consideration where resistance to FHB is an important breeding target. As an alternative, marker-assisted introgression of the newly reported semidwarfing allele, Rht $24 b$ (Herter et al. 2018), or other alternative stem shortening alleles, into elite durum wheat might provide the desired plant height without increasing susceptibility to FHB.

There have also been attempts to engineer resistance to Fusarium in wheat and other crops, which could serve as a viable option for durum wheat; however, regulatory hurdles as well as the acceptance of genetically modified materials in global markets remain as major obstacles to the production of genetically modified wheat (Okubara et al. 2002). Although wheat is a selfpollinated crop, there is also the potential for outcrossing. Taken together, genetically modified durum wheat that is resistant to Fusarium is unlikely to be an acceptable solution to the current susceptibility problem.

In summary, efficient use of the native resistance present in the elite durum wheat gene pool, and introgression of resistance alleles from relatives and bread wheat, the FHB resistance level in durum wheat can be improved. The speed of this process may also be enhanced through modernizing the phenotyping process and by implementing genomic selection strategies.

\section{LITERATURE CITED}

Anderson, J. A. 2007. Marker-assisted selection for Fusarium head blight resistance in wheat. Int. J. Food Microbiol. 119:51-53.

Arruda, M. P., Brown, P., Brown-Guedira, G., Krill, A. M., Thurber, C., Merrill, K. R., Foresman, B. J., and Kolb, F. L. 2016a. Genome-wide association mapping of Fusarium head blight resistance in wheat using genotyping-by-sequencing. Plant Genome 9:1-14.

Arruda, M. P., Brown, P. J., Lipka, A. E., Krill, A. M., Thurber, C., and Kolb, F. L. 2015. Genomic selection for predicting Fusarium head blight resistance in a wheat breeding program. Plant Genome 8:1-12.

Arruda, M. P., Lipka, A. E., Brown, P. J., Krill, A. M., Thurber, C., Brown-Guedira, G., Dong, Y., Foresman, B. J., and Kolb, F. L. 2016 b. Comparing genomic selection and marker-assisted selection for Fusarium head blight resistance in wheat (Triticum aestivum L.). Mol. Breed. 36:84.

Ashiq, S. 2015. Natural occurrence of mycotoxins in food and feed: Pakistan perspective. Compr. Rev. Food Sci. Food Saf. 14:159-175.

Bai, G., and Shaner, G. 1994. Scab of wheat: Prospects for control. Plant Dis. 78:760-766.

Bai, G., and Shaner, G. 2004. Management and resistance in wheat and barley to Fusarium head blight. Annu. Rev. Phytopathol. 42:135-161. 
Bai, G., Su, Z., and Cai, J. 2018. Wheat resistance to Fusarium head blight. Can. J. Plant Pathol. 40:336-346.

Bai, G.-H., Shaner, G., and Ohm, H. 2000. Inheritance of resistance to Fusarium graminearum in wheat. Theor. Appl. Genet. 100:1-8.

Ban, T., and Watanabe, N. 2001. The effects of chromosomes 3A and 3B on resistance to Fusarium head blight in tetraploid wheat. Hereditas 135: 95-99.

Bassi, F. M., Bentley, A. R., Charmet, G., Ortiz, R., and Crossa, J. 2016. Breeding schemes for the implementation of genomic selection in wheat (Triticum spp.). Plant Sci. 242:23-36.

Beccari, G., Colasante, V., Tini, F., Senatore, M. T., Prodi, A., Sulyok, M., and Covarelli, L. 2017. Causal agents of Fusarium head blight of durum wheat (Triticum durum Desf.) in central Italy and their in vitro biosynthesis of secondary metabolites. Food Microbiol. 70:17-27.

Beccari, G., Prodi, A., Tini, F., Bonciarelli, U., Onofri, A., Oueslati, S., Limayma, M., and Covarelli, L. 2017b. Changes in the Fusarium head blight complex of malting barley in a three-year field experiment in Italy. Toxins (Basel) 9:120.

Bellincampi, D., Cervone, F., and Lionetti, V. 2014. Plant cell wall dynamics and wall-related susceptibility in plant-pathogen interactions. Front. Plant Sci. 5:228.

Berghofer, L. K., Hocking, A. D., Miskelly, D., and Jansson, E. 2003. Microbiology of wheat and flour milling in Australia. Int. J. Food Microbiol. 85:137-149.

Bockus, W., Bowden, R., Hunger, R., Morrill, W., Murray, T., and Smiley, R. 2010. Compendium of Wheat Diseases and Pests, 3rd Ed. American Phytopathological Society, St. Paul, MN.

Bryła, M., Ksieniewicz-Wozniak, E., Yoshinari, T., Waskiewicz, A., and Szymczyk, K. 2019. Contamination of wheat cultivated in various regions of Poland during 2017 and 2018 agricultural seasons with selected trichothecenes and their modified forms. Toxins (Basel) 11:88.

Buerstmayr, H., Ban, T., and Anderson, J. A. 2009. QTL mapping and markerassisted selection for Fusarium head blight resistance in wheat: A review. Plant Breed. 128:1-26.

Buerstmayr, H., Buerstmayr, M., Schweiger, W., and Steiner, B. 2014. Breeding for resistance to head blight caused by Fusarium spp. in wheat. CAB Reviews 9.

Buerstmayr, H., Steiner, B., Hartl, L., Griesser, M., Angerer, N., Lengauer, D., Miedaner, T., Schneider, B., and Lemmens, M. 2003. Molecular mapping of QTLs for Fusarium head blight resistance in spring wheat. II. Resistance to fungal penetration and spread. Theor. Appl. Genet. 107:503-508.

Buerstmayr, M., Alimari, A., Steiner, B., and Buerstmayr, H. 2013. Genetic mapping of QTL for resistance to Fusarium head blight spread (type 2 resistance) in a Triticum dicoccoides $\times$ Triticum durum backcross-derived population. Theor. Appl. Genet. 126:2825-2834.

Buerstmayr, M., and Buerstmayr, H. 2015. Comparative mapping of quantitative trait loci for Fusarium head blight resistance and anther retention in the winter wheat population Capo $\times$ Arina. Theor. Appl. Genet. 128: 1519-1530.

Buerstmayr, M., and Buerstmayr, H. 2016. The semidwarfing alleles Rht-D1b and Rht-B1b show marked differences in their associations with antherretention in wheat heads and with Fusarium head blight susceptibility. Phytopathology 106:1544-1552.

Buerstmayr, M., Huber, K., Heckmann, J., Steiner, B., Nelson, J. C., and Buerstmayr, H. 2012. Mapping of QTL for Fusarium head blight resistance and morphological and developmental traits in three backcross populations derived from Triticum dicoccum $\times$ Triticum durum. Theor. Appl. Genet. 125:1751-1765.

Bullerman, L. B., and Bianchini, A. 2007. Stability of mycotoxins during food processing. Int. J. Food Microbiol. 119:140-146.

Cakmak, I., Pfeiffer, W., and McClafferty, B. 2010. REVIEW: Biofortification of durum wheat with zinc and iron. Cereal Chem. 87:10-20.

Callaway, E. 2018. CRISPR plants now subject to tough GM laws in European Union. Nature 560:16.

Campbell, J., Zhang, H., Giroux, M. J., Feiz, L., Jin, Y., Wang, M., Chen, X., and Huang, L. 2012. A mutagenesis-derived broad-spectrum disease resistance locus in wheat. Theor. Appl. Genet. 125:391-404.

Canadian Grain Commission. 2018. Official Grain Grading Guide: Pages 4-38 in: Wheat. https://www.grainscanada.gc.ca/en/grain-quality/officialgrain-grading-guide/

Chen, X., Faris, J. D., Hu, J., Stack, R. W., Adhikari, T., Elias, E. M., Kianian, S. F., and Cai, X. 2007. Saturation and comparative mapping of a major Fusarium head blight resistance QTL in tetraploid wheat. Mol. Breed. 19: 113-124.

Chilaka, C., De Boevre, M., Atanda, O., and De Saeger, S. 2017. The status of Fusarium mycotoxins in Sub-Saharan Africa: A review of emerging trends and post-harvest mitigation strategies towards food control. Toxins (Basel) 9:19.
Clarke, J. M., Clarke, F. R., and Pozniak, C. J. 2010. Forty-six years of genetic improvement in Canadian durum wheat cultivars. Can. J. Plant Sci. 90: 791-801.

Covarelli, L., Beccari, G., Prodi, A., Generotti, S., Etruschi, F., Juan, C., Ferrer, E., and Manes, J. 2015. Fusarium species, chemotype characterisation and trichothecene contamination of durum and soft wheat in an area of central Italy. J. Sci. Food Agric. 95:540-551.

Crossa, J., Campos, G., Pérez, P., Gianola, D., Burgueño, J., Araus, J. L., Makumbi, D., Singh, R. P., Dreisigacker, S., Yan, J., Arief, V., Banziger, M., and Braun, H.-J. 2010. Prediction of genetic values of quantitative traits in plant breeding using pedigree and molecular markers. Genetics 186: 713-724.

Dexter, J., and Edwards, N. 1998. The Implications of Frequently Encountered Grading Factors on the Processing Quality of Durum Wheat. Association of Operative Millers-Bulletin Presented at the 102nd Association of Operative Millers (AOM) Trade Show, Phoenix, Arizona.

Dexter, J., Marchylo, B., Clear, R., and Clarke, J. 1997. Effect of Fusarium head blight on semolina milling and pasta-making quality of durum wheat. Cereal Chem. 74:519-525.

Ding, L., Xu, H., Yi, H., Yang, L., Kong, Z., Zhang, L., Xue, S., Jia, H., and Ma, Z. 2011. Resistance to hemi-biotrophic $F$. graminearum infection is associated with coordinated and ordered expression of diverse defense signaling pathways. PLoS One 6:e19008.

Dong, H., Wang, R., Yuan, Y., Anderson, J., Pumphrey, M., Zhang, Z., and Chen, J. 2018. Evaluation of the potential for genomic selection to improve spring wheat resistance to Fusarium head blight in the Pacific Northwest. Front. Plant Sci. 9:911

Draeger, R., Gosman, N., Steed, A., Chandler, E., Thomsett, M., Srinivasachary, Schondelmaier, J., Buerstmayr, H., Lemmens, M., Schmolke, M., Mesterhazy, A., and Nicholson, P. 2007. Identification of QTLs for resistance to Fusarium head blight, DON accumulation and associated traits in the winter wheat variety Arina. Theor. Appl. Genet. 115: 617-625.

Dweba, C. C., Figlan, S., Shimelis, H. A., Motaung, T. E., Sydenham, S., Mwadzingeni, L., and Tsilo, T. J. 2017. Fusarium head blight of wheat: Pathogenesis and control strategies. Crop Prot. 91:114-122.

European-Commission. 2007. Commission Regulation (EC) 1126/2007 of 28 September 2007 amending Regulation (EC) 1881/2006 setting maximum levels for certain contaminants in foodstuffs as regards Fusarium toxins in maize and maize products. Official Journal of the European Communities, L255, $14 \mathrm{e} 17$.

Fakhfakh, M., Yahyaoui, A., Rezgui, S., Elias, E. M., and Daaloul, A. 2011. Inheritances of Fusarium head blight resistance in a cross involving local and exotic durum wheat cultivars. Crop Sci. 51:2517-2524.

Ficco, D. B. M., Mastrangelo, A. M., Trono, D., Borrelli, G. M., De Vita, P., Fares, C., Beleggia, R., Platani, C., and Papa, R. 2014. The colours of durum wheat: A review. Crop Pasture Sci. 65:1-15.

Food and Drug Administration (FDA). 2016. Chemical contaminants, metals, natural toxins \& pesticides guidance documents \& regulations. U.S. Food and Drug Administration.

Gale, L. 2003. Population biology of Fusarium species causing head blight of grain grops. Pages 120-143 in: Fusarium Head Blight of Wheat and Barley. K. J. Leonard and W. R. Bushnell, eds. American Phytopathological Society, St. Paul, MN.

Ghavami, F., Elias, E. M., Mamidi, S., Ansari, O., Sargolzaei, M., Adhikari, T., Mergoum, M., and Kianian, S. F. 2011. Mixed model association mapping for Fusarium head blight resistance in Tunisian-derived durum wheat populations. G3:Genes|Genomes|Genetics 1:209-218.

Giancaspro, A., Giove, S. L., Zito, D., Blanco, A., and Gadaleta, A. 2016. Mapping QTLs for Fusarium head blight resistance in an interspecific wheat population. Front. Plant Sci. 7:1381.

Gilbert, J., and Haber, S. 2013. Overview of some recent research developments in Fusarium head blight of wheat. Can. J. Plant Pathol. 35:149-174.

Gilbert, J., and Tekauz, A. 2000. Review: Recent developments in research on Fusarium head blight of wheat in Canada. Can. J. Plant Pathol. 22:1-8.

Gladysz, C., Lemmens, M., Steiner, B., and Buerstmayr, H. 2007. Evaluation and genetic mapping of resistance to Fusarium head blight in Triticum dicoccoides. Isr. J. Plant Sci. 55:263-266.

Häggblom, P., and Nordkvist, E. 2015. Deoxynivalenol, zearalenone, and Fusarium graminearum contamination of cereal straw; field distribution; and sampling of big bales. Mycotoxin Res. 31:101-107.

He, X., Lillemo, M., Shi, J., Wu, J., Bjørnstad, Å., Belova, T., Dreisigacker, S., Duveiller, E., and Singh, P. 2016. QTL characterization of Fusarium head blight resistance in CIMMYT bread wheat line Soru\#1. PLoS One 11: e0158052.

He, Y., Zhang, X., Zhang, Y., Ahmad, D., Wu, L., Jiang, P., and Ma, H. 2018. Molecular characterization and expression of PFT, an FHB resistance gene at the Fhb1 QTL in wheat. Phytopathology 108:730-736. 
Health Canada. 2016. Canadian standards (maximum limits) for various chemical contaminants in foods. https://www.canada.ca/en/health-canada/ services/food-nutrition/food-safety/chemical-contaminants/maximum-levelschemical-contaminants-foods.html

Heffner, E. L., Lorenz, A. J., Jannink, J.-L., and Sorrells, M. E. 2010. Plant breeding with genomic selection: Gain per unit time and cost. Crop Sci. 50: 1681-1690.

Henry, I. M., Nagalakshmi, U., Lieberman, M. C., Ngo, K. J., Krasileva, K. V., Vasquez-Gross, H., Akhunova, A., Akhunov, E., Dubcovsky, J., Tai, T. H., and Comai, L. 2014. Efficient genome-wide detection and cataloging of EMS-induced mutations using exome capture and next-generation sequencing. Plant Cell 26:1382-1397.

Herter, C. P., Ebmeyer, E., Kollers, S., Korzun, V., Leiser, W. L., Wurschum, T., and Miedaner, T. 2018. Rht 24 reduces height in the winter wheat population 'Solitar $\times$ Bussard' without adverse effects on Fusarium head blight infection. Theor. Appl. Genet. 131:1263-1272.

Heslot, N., Akdemir, D., Sorrells, M. E., and Jannink, J. L. 2014. Integrating environmental covariates and crop modeling into the genomic selection framework to predict genotype by environment interactions. Theor. Appl. Genet. 127:463-480.

Huhn, M. R., Elias, E., Ghavami, F., Kianian, S., Chao, S., Zhong, S. S., Alamri, M., Yahyaoui, A., and Mergoum, M. 2012. Tetraploid Tunisian wheat germplasm as a new source of Fusarium head blight resistance. Crop Sci. 52:136-145.

Jansen, C., von Wettstein, D., Schafer, W., Kogel, K.-H., Felk, A., and Maier, F. J. 2005. Infection patterns in barley and wheat spikes inoculated with wild-type and trichodiene synthase gene disrupted Fusarium graminearum. PNAS 102:16892-16897.

Jiang, Y., Zhao, Y., Rodemann, B., Plieske, J., Kollers, S., Korzun, V., Ebmeyer, E., Argillier, O., Hinze, M., Ling, J., Röder, M. S., Ganal, M. W., Mette, M. F., and Reif, J. C. 2014. Potential and limits to unravel the genetic architecture and predict the variation of Fusarium head blight resistance in European winter wheat (Triticum aestivum L.). Heredity 114:318-326.

Jones, J. D., and Dangl, J. L. 2006. The plant immune system. Nature 444: 323-329.

Kage, U., Karre, S., Kushalappa, A. C., and McCartney, C. 2017. Identification and characterization of a fusarium head blight resistance gene TaACT in wheat QTL-2DL. Plant Biotechnol. J. 15:447-457.

Kazan, K., Gardiner, D. M., and Manners, J. M. 2012. On the trail of a cereal killer: Recent advances in Fusarium graminearum pathogenomics and host resistance. Mol. Plant Pathol. 13:399-413.

Kelly, A. C., Clear, R. M., O’Donnell, K., McCormick, S., Turkington, T. K., Tekauz, A., Gilbert, J., Kistler, H. C., Busman, M., and Ward, T. J. 2015. Diversity of Fusarium head blight populations and trichothecene toxin types reveals regional differences in pathogen composition and temporal dynamics. Fungal Genet. Biol. 82:22-31.

Klahr, A., Zimmermann, G., Wenzel, G., and Mohler, V. 2007. Effects of environment, disease progress, plant height and heading date on the detection of QTLs for resistance to Fusarium head blight in an European winter wheat cross. Euphytica 154:17-28.

Köksel, H., Sapirstein, H. D., Çelik, S., and Bushuk, W. 1998. Effects of gamma-irradiation of wheat on gluten proteins. J. Cereal Sci. 28: 243-250.

Krasileva, K. V., Vasquez-Gross, H. A., Howell, T., Bailey, P., Paraiso, F., Clissold, L., Simmonds, J., Ramirez-Gonzalez, R. H., Wang, X., Borrill, P., Fosker, C., Ayling, S., Phillips, A. L., Uauy, C., and Dubcovsky, J. 2017. Uncovering hidden variation in polyploid wheat. Proc. Natl. Acad. Sci. 114: E913-E921.

Kumar, S., Stack, R. W., Friesen, T. L., and Faris, J. D. 2007. Identification of a novel Fusarium head blight resistance quantitative trait locus on chromosome 7A in tetraploid wheat. Phytopathology 97:592-597.

Li, X., Michlmayr, H., Schweiger, W., Malachova, A., Shin, S., Huang, Y., Dong, Y., Wiesenberger, G., McCormick, S., Lemmens, M., Fruhmann, P., Hametner, C., Berthiller, F., Adam, G., and Muehlbauer, G. J. 2017. A barley UDP-glucosyltransferase inactivates nivalenol and provides Fusarium head blight resistance in transgenic wheat. J. Exp. Bot. 68: 2187-2197.

Lionetti, V., Giancaspro, A., Fabri, E., Giove, S. L., Reem, N., Zabotina, O. A., Blanco, A., Gadaleta, A., and Bellincampi, D. 2015. Cell wall traits as potential resources to improve resistance of durum wheat against Fusarium graminearum. BMC Plant Biol. 15:6.

Liu, S., and Anderson, J. A. 2003. Targeted molecular mapping of a major wheat QTL for Fusarium head blight resistance using wheat ESTs and synteny with rice. Genome 46:817-823.

Lu, Q., Lillemo, M., Skinnes, H., He, X., Shi, J., Ji, F., Dong, Y., and Bjørnstad, A. 2012. Anther extrusion and plant height are associated with Type I resistance to Fusarium head blight in bread wheat line 'Shanghai-3/ Catbird'. Theor. Appl. Genet. 126:317-334.
Maccaferri, M., Harris, N., Twardziok, S., Pasam, R., Gundlach, H., et al. 2019. Durum wheat genome highlights past domestication signatures and future improvement targets. Nature Genetics 51:885-895.

Maccaferri, M., Ricci, A., Salvi, S., Milner, S. G., Noli, E., et al. 2015. A highdensity, SNP-based consensus map of tetraploid wheat as a bridge to integrate durum and bread wheat genomics and breeding. Plant Biotechnol. J. 13:648-663.

Magan, N., and Aldred, D. 2007. Post-harvest control strategies: Minimizing mycotoxins in the food chain. Int. J. Food Microbiol. 119:131-139.

Manthey, F. A., Wolf-Hall, C. E., Yalla, S., Vijayakumar, C., and Carlson, D. 2004. Microbial loads, mycotoxins, and quality of durum wheat from the 2001 harvest of the northern plains region of the United States. J. Food Prot. 67:772-780.

Martin, C., Schoneberg, T., Vogelgsang, S., Vincenti, J., Brtossa, M., Mauch-Mani, B., and Mascher, F. 2017. Factors of wheat grain resistance to Fusarium head blight. Phytopathol. Mediterr. 56:154-166.

McCallum, C. M., Comai, L., Greene, E. A., and Henikoff, S. 2000. Targeting induced local lesions IN genomes (TILLING) for plant functional genomics. Plant Physiol. 123:439-442.

McCartney, C. A., Brûlé-Babel, A. L., Fedak, G., Martin, R. A., McCallum, B. D., Gilbert, J., Hiebert, C. W., and Pozniak, C. J. 2016. Fusarium head blight resistance QTL in the spring wheat cross Kenyon/86ISMN 2137. Front. Microbiol. 7:1542.

McMullen, M., Bergstrom, G., De Wolf, E., Dill-macky, R., Hershman, D., Shaner, G., and Van Sanford, D. 2012. A unified effort to fight an enemy of wheat and barley: Fusarium head blight. Plant Dis. 96:1712-1728.

Meuwissen, T. H., Hayes, B. J., and Goddard, M. E. 2001. Prediction of total genetic value using genome-wide dense marker maps. Genetics 157: 1819-1829.

Miedaner, T. 1997. Breeding wheat and rye for resistance to Fusarium diseases. Plant Breed. 116:201-220.

Miedaner, T., and Longin, C. F. H. 2014. Genetic variation for resistance to Fusarium head blight in winter durum material. Crop Pasture Sci. 65:46-51.

Miedaner, T., Sieber, A.-N., Desaint, H., Buerstmayr, H., Longin, C. F. H., and Würschum, T. 2017. The potential of genomic-assisted breeding to improve Fusarium head blight resistance in winter durum wheat. Plant Breed. 136: 610-619.

Mirdita, V., He, S., Zhao, Y., Korzun, V., Bothe, R., Ebmeyer, E., Reif, J. C., and Jiang, Y. 2015a. Potential and limits of whole genome prediction of resistance to Fusarium head blight and Septoria tritici blotch in a vast Central European elite winter wheat population. Theor. Appl. Genet. 128: 2471-2481.

Mirdita, V., Liu, G., Zhao, Y., Miedaner, T., Longin, C. F. H., Gowda, M., Mette, M. F., and Reif, J. C. 2015b. Genetic architecture is more complex for resistance to Septoria tritici blotch than to Fusarium head blight in Central European winter wheat. BMC Genomics 16:430.

Mishra, A., Singh, A., Sharma, M., Kumar, P., and Roy, J. 2016. Development of EMS-induced mutation population for amylose and resistant starch variation in bread wheat (Triticum aestivum) and identification of candidate genes responsible for amylose variation. BMC Plant Biol. 16:217.

Okubara, P., Blechl, A., McCormick, S., Alexander, N., Dill-Macky, R., and Hohn, T. 2002. Engineering deoxynivalenol metabolism in wheat through the expression of a fungal trichothecene acetyltransferase gene. Theor. Appl. Genet. 106:74-83.

Osborne, L. E., and Stein, J. M. 2007. Epidemiology of Fusarium head blight on small-grain cereals. Int. J. Food Microbiol. 119:103-108.

Otto, C. D., Kianian, S. F., Elias, E. M., Stack, R. W., and Joppa, L. R. 2002. Genetic dissection of a major Fusarium head blight QTL in tetraploid wheat. Plant Mol. Biol. 48:625-632.

Periyannan, S., Milne, R. J., Figueroa, M., Lagudah, E. S., and Dodds, P. N. 2017. An overview of genetic rust resistance: From broad to specific mechanisms. PLoS Pathog 13:e1006380.

Pogorelko, G., Lionetti, V., Bellincampi, D., and Zabotina, O. 2013. Cell wall integrity: Targeted post-synthetic modifications to reveal its role in plant growth and defense against pathogens. Plant Signal. Behav. 8:9.

Poland, J., Endelman, J., Dawson, J., Rutkoski, J., Wu, S., Manes, Y., Dreisigacker, S., Crossa, J., Sánchez-Villeda, H., Sorrells, M., and Jannink, J.-L. 2012. Genomic selection in wheat breeding using genotyping-by-sequencing. Plant Genome 5:103-113.

Poland, J., and Rutkoski, J. 2016. Advances and challenges in genomic selection for disease resistance. Annu. Rev. Phytopathol. 54:79-98.

Prat, N., Buerstmayr, M., Steiner, B., Robert, O., and Buerstmayr, H. 2014. Current knowledge on resistance to Fusarium head blight in tetraploid wheat. Mol. Breed. 34:1689-1699.

Prat, N., Guilbert, C., Prah, U., Wachter, E., Steiner, B., Langin, T., Robert, O., and Buerstmayr, H. 2017. QTL mapping of Fusarium head blight resistance in three related durum wheat populations. Theor. Appl. Genet. 130:13-27. 
Rawat, N., Pumphrey, M. O., Liu, S., Zhang, X., Tiwari, V. K., Ando, K., Trick, H. N., Bockus, W. W., Akhunov, E., Anderson, J. A., and Gill, B. S. 2016. Wheat Fhb1 encodes a chimeric lectin with agglutinin domains and a pore-forming toxin-like domain conferring resistance to Fusarium head blight. Nat. Genet. 48:1576-1580.

Rosewarne, G. M., Singh, R. P., Huerta-Espino, J., and Rebetzke, G. J. 2008. Quantitative trait loci for slow-rusting resistance in wheat to leaf rust and stripe rust identified with multi-environment analysis. Theor. Appl. Genet. 116:1027-1034

Ruan, Y., Comeau, A., Langevin, F., Hucl, P., Clarke, J. M., Brule-Babel, A., and Pozniak, C. J. 2012. Identification of novel QTL for resistance to Fusarium head blight in a tetraploid wheat population. Genome 55:853-864.

Rutkoski, J., Benson, J., Jia, Y., Brown-Guedira, G., Jannink, J.-L., and Sorrells, M. 2012. Evaluation of genomic prediction methods for Fusarium head blight resistance in wheat. The Plant Genome 5:51-61.

Rutkoski, J. E., Crain, J., Poland, J., and Sorrells, M. E. 2017. Genomic Selection for Small Grain Improvement. Pages 99-130 in: Genomic Selection for Crop Improvement: New Molecular Breeding Strategies for Crop Improvement. R. K. Varshney, M. Roorkiwal, and M. E. Sorrells, eds. Springer International Publishing, Cham.

Sallam, A. H., Endelman, J. B., Jannink, J. L., and Smith, K. P. 2015. Assessing genomic selection prediction accuracy in a dynamic barley breeding population. The Plant Genome 8.

Sari, E., Berraies, S., Knox, R. E., Singh, A. K., Ruan, Y., Cuthbert, R. D., Pozniak, C. J., Henriquez, M. A., Kumar, S., Burt, A. J., N'Diaye, A., Konkin, D. J., Cabral, A. L., Campbell, H. L., Wiebe, K., Condie, J., Lokuruge, P., Meyer, B., Fedak, G., Clarke, F. R., Clarke, J. M., Somers, D. J., and Fobert, P. R. 2018. High density genetic mapping of Fusarium head blight resistance QTL in tetraploid wheat. PLoS One 13:e0204362.

Scala, V., Aureli, G., Cesarano, G., Incerti, G., Fanelli, C., Scala, F., Reverberi, M., and Bonanomi, G. 2016. Climate, soil management, and cultivar affect Fusarium head blight incidence and deoxynivalenol accumulation in durum wheat of Southern Italy. Front. Microbiol. 7:1014.

Schmolke, M., Zimmermann, G., Buerstmayr, H., Schweizer, G., Miedaner, T., Korzun, V., Ebmeyer, E., and Hartl, L. 2005. Molecular mapping of Fusarium head blight resistance in the winter wheat population Dream/ Lynx. Theor. Appl. Genet. 111:747-756.

Shah, L., Ali, A., Yahya, M., Zhu, Y., Wang, S., Si, H., Rahman, H., and Ma, C. 2018. Integrated control of fusarium head blight and deoxynivalenol mycotoxin in wheat. Plant Pathol. 67:532-548.

Shahin, M. A., Hatcher, D. W., and Symons, S. J. 2012. Development of multispectral imaging systems for quality evaluation of cereal grains and grain products. Pages 451-482 in: Computer Vision Technology in the Food and Beverage Industries. D.-W. Sun, ed. Woodhead Publishing.

Shakoor, N., Lee, S., and Mockler, T. C. 2017. High throughput phenotyping to accelerate crop breeding and monitoring of diseases in the field. Curr. Opin. Plant Biol. 38:184-192.

Shaner, G. 2003. Pages 84-119 in: Epidemiology of Fusarium head blight of small grain cereals in North America. K. J. Leonard, and W. R. Bushnell, eds. American Phytopathological Society, St. Paul, MN.

Skinnes, H., Semagn, K., Tarkegne, Y., Marøy, A. G., and Bjørnstad, Å. 2010. The inheritance of anther extrusion in hexaploid wheat and its relationship to Fusarium head blight resistance and deoxynivalenol content. Plant Breed. 129:149-155.

Slade, A. J., Fuerstenberg, S. I., Loeffler, D., Steine, M. N., and Facciotti, D. 2005. A reverse genetic, nontransgenic approach to wheat crop improvement by TILLING. Nat. Biotechnol. 23:75-81.

Srinivasachary, Gosman, N., Steed, A., Hollins, T. W., Bayles, R., Jennings, P., and Nicholson, P. 2009. Semi-dwarfing Rht-B1 and Rht-D1 loci of wheat differ significantly in their influence on resistance to Fusarium head blight. Theor. Appl. Genet. 118:695-702.

Statistics Canada. 2018. Table 32-10-0359-01 Estimated areas, yield, production, average farm price and total farm value of principal field crops, in metric and imperial units. https://www150.statcan.gc.ca/t1/tbl1/en/tv. action?pid $=3210035901$
Steiner, B., Buerstmayr, M., Michel, S., Schweiger, W., Lemmens, M., and Buerstmayr, H. 2017. Breeding strategies and advances in line selection for Fusarium head blight resistance in wheat. Trop. Plant Pathol. 42:165-174.

Steiner, B., Michel, S., Maccaferri, M., Lemmens, M., Tuberosa, R., and Buerstmayr, H. 2019. Exploring and exploiting the genetic variation of Fusarium head blight resistance for genomic-assisted breeding in the elite durum wheat gene pool. Theor. Appl. Genet. 132:969-988.

Tedone, L., Alhajj Ali, S., and De Mastro, G. 2017. Optimization of nitrogen in durum wheat in the Mediterranean climate: The agronomical aspect and greenhouse gas (GHG) emissions nitrogen in agriculture, Amanullah and S. Fahad, IntechOpen. https://www.intechopen.com/books/nitrogen-in-agricultureupdates/optimization-of-nitrogen-in-durum-wheat-in-the-mediterraneanclimate-the-agronomical-aspect-and-gree

Tessmann, E., and Van Sanford, D. 2018. GWAS for Fusarium head blight related traits in winter wheat (Triticum aestivum L.) in an artificially warmed treatment. Agronomy (Basel) 8:68.

Thapa, G., Gunupuru, L. R., Hehir, J. G., Kahla, A., Mullins, E., and Doohan, F. M. 2018. A pathogen-responsive leucine rich receptor like kinase contributes to Fusarium resistance in cereals. Front. Plant Sci. 9:867.

Thielecke, F., and Nugent, A. P. 2018. Contaminants in grain-A major risk for whole grain safety? Nutrients 10:1213.

Trail, F. 2009. For blighted waves of grain: Fusarium graminearum in the postgenomics era. Plant Physiol. 149:103-110.

Tuberosa, R., and Pozniak, C. 2014. Durum wheat genomics comes of age. Mol. Breed. 34:1527-1530.

Turkington, T., Petran, A., Yonow, T., and Kriticos, D. 2014. Fusarium graminearum. HarvestChoice Pest Geography, InSTePP-HarvestChoice, St. Paul, MN.

van Schie, C. C., and Takken, F. L. 2014. Susceptibility genes 101: How to be a good host. Annu. Rev. Phytopathol. 52:551-581.

Visconti, A., Haidukowski, E. M., Pascale, M., and Silvestri, M. 2004. Reduction of deoxynivalenol during durum wheat processing and spaghetti cooking. Toxicol. Lett. 153:181-189.

Walkowiak, S., Bonner, C. T., Wang, L., Blackwell, B., Rowland, O., and Subramaniam, R. 2015. Intraspecies interaction of Fusarium graminearum contributes to reduced toxin production and virulence. Mol. Plant-Microbe Interact. 28:1256-1267.

Wang, R., Chen, J., Anderson, J. A., Zhang, J., Zhao, W., Wheeler, J., Klassen, N., See, D. R., and Dong, Y. 2017. Genome-wide association mapping of Fusarium head blight resistance in spring wheat lines developed in the Pacific Northwest and CIMMYT. Phytopathology 107: 1486-1495.

Wegulo, S. N. 2012. Factors influencing deoxynivalenol accumulation in small grain cereals. Toxins (Basel) 4:1157-1180.

Wiese, M., Murray, T., and Forster, R. 2000. Common names of plant diseases: Diseases of wheat. American Phytopathological Society, St. Paul, MN.

Wilde, F., Korzun, V., Ebmeyer, E., Geiger, H. H., and Miedaner, T. 2007. Comparison of phenotypic and marker-based selection for Fusarium head blight resistance and DON content in spring wheat. Mol. Breed. 19: 357-370.

Yan, W., Li, H. B., Cai, S. B., Ma, H. X., Rebetzke, G. J., and Liu, C. J. 2011. Effects of plant height on type I and type II resistance to Fusarium head blight in wheat. Plant Pathol. 60:506-512.

Zhang, Q., Axtman, J. E., Faris, J. D., Chao, S., Zhang, Z., Friesen, T. L., Zhong, S., Cai, X., Elias, E. M., and Xu, S. S. 2014. Identification and molecular mapping of quantitative trait loci for Fusarium head blight resistance in emmer and durum wheat using a single nucleotide polymorphismbased linkage map. Mol. Breed. 34:1677-1687.

Zhao, M., Leng, Y., Chao, S., Xu, S. S., and Zhong, S. 2018. Molecular mapping of QTL for Fusarium head blight resistance introgressed into durum wheat. Theor. Appl. Genet. 131:1939-1951.

Zhou, F. 2011. Review of compendium of wheat diseases and pests. J. Agric. Food Inf. 12:210. 